\title{
Root Resection in Molars: Clinical Evaluation for 10 Years
}

\author{
Resección de la Raíz en Molares: Evaluación Clínica Durante 10 años

\begin{abstract}
Márcio Eduardo Vieira Falabella1; Raylla Jennifer Silva de Souza'; Amanda Hastenreiter Costa Dornelas ${ }^{1}$; Antônio Dimas Duarte Vieira² \& Leo Guimarães Soares ${ }^{3}$
\end{abstract}

FALABELLA, M. E. V.; DE SOUZA, R. J. S.; DORNELAS, A. H. C.; VIEIRA, A. D. D. \& SOARES, L. G. Root resection in molars - clinical evaluation for 10 years. Int. J. Odontostomat., 15(2):492-498, 2021.

ABSTRACT: Root resection (RR) is a therapeutic option for furcation lesions grade II and III, fracture of one of the roots and root caries. The aim of the study was to evaluate in each selected period (5, 8 and 10 years) the percentage of maintenance of molars that underwent RR therapy with furcation lesions grade II and III or with root fractures. Subjects received the therapy with $\mathrm{RR}$ in molars with periodontitis, with furcation lesion grades II or III, and with fractures, caries or endodontic reason, in one of the roots. The supportive periodontal therapy was made for at least one annual session during the assessed time. For the clinical therapy to be considered successful, the tooth is remaining in functional loading, without mobility above grade I, pocket depth $\geq 4 \mathrm{~mm}$, absence of bleeding on probing or exudate, fractures and root caries. Were evaluated the files of 37 patients, 15 males and 22 females, with a mean age of $51.4(S D= \pm 12.46)$, with a total of 44 teeth with RR, 27 upper and 17 lower molars. The survival rates after the RR was $97.73 \%$ for 05 years of evaluation (44 teeth), $95.35 \%$ for the 08 years (43 teeth) and $97.57 \%$ for the 10 years (41 teeth). 35 teeth were restored with total crows isolated or abutment of fixed prosthesis. The survival rates after 10-years was $90.91 \%$, and there was no statistical difference between the types of restorations performed and the tooth survival rate.

KEY WORDS: furcation defects, periodontal diseases, dental prosthesis.

\section{INTRODUCTION}

Periodontal disease is a pathology with a multifactorial etiology associated with alveolar bone resorption, and with a series of systemic and local factors that can influence the prognosis of the affected teeth. (Jenabian et al., 2013).

The conventional periodontal therapy is based on the control of the biofilm adhered to the root surfaces and presents better results in uniradicular teeth when compared with multiradicular teeth (Nordland et al., 1987; Wang et al., 1994), with these teeth showing a higher percentage of loss.

Furcation lesions are characterized by the extension of the periodontal pocket in the furcation area and its diagnosis is made by conventional clinical and radiographic exams, although often failing to determine the real involvement of the furcation (Svärdström \& Wennström, 2000). Gusmão et al. (2014) showed that a significant percentage of molars in patients with chronic periodontitis had furcation lesions, and that the upper and lower first molars were the teeth most affected, with grade II involvement the most common. Upper molars were more frequently diagnosed with furcation lesions than lower molars, $72 \%$ and $50 \%$ respectively, according to Walter et al. (2011).

The therapy of furcation lesions by subgingival scaling and root planing should be performed as the first option in most cases with an expectation of high longterm survival of the teeth, since they are submitted to a periodontal supportive therapy (Cattabriga et al., 2020).

\footnotetext{
${ }^{1}$ School of Dentistry, Federal University of Juiz de Fora, Minas Gerais, Brazil.

${ }^{2}$ Specialization course in Dental Prosthesis - Brazilian Association of Dentistry - Juiz de Fora - MG, Brazil.

${ }^{3}$ State University of Rio de Janeiro - Brazil

Received: 2020-08-04

Accepted: $2020-11-20$
}

492 
Root resection (RR) is a therapeutic option for furcation lesions and are resective surgical procedures that overcome the limitations of scaling at furcation areas, with indication in furcation lesions grade II and III, fracture of one of the roots and root caries, in which other roots are in good clinical condition (Almeida et al., 2012).

Huynh-Ba et al. (2009) performed a systematic review on the result of RR in molars and reported a survival rate between 62 and $100 \%$. Park et al. (2009) evaluated molars with RR for 10 years, and showed a loss of $29.8 \%$ in 342 teeth, and the failures in the upper molars were more due to periodontal causes, while in the lower ones due to caries or fractures.

Carnevale et al. (1998) also evaluated the result of RR in 175 teeth with 10 years of monitoring. Flap surgeries for root extraction were associated with the apically positioned flap and osteoplasty. The survival of the roots was $93 \%$ in the evaluated period and dependent on obtaining a tissue morphology favorable to hygiene of the area and adequate prosthetic restoration.

The indication for RR should be discussed with the possibility of tooth extraction and replacement by implants, especially when there are complicating factors such as reduced periodontal attachment in the remaining roots, prosthetic and endodontic difficulties (Kinsel et al., 1998). Fugazzoto (2001) examined the success rate of RR and implants, in 701 teeth and 1472 implants installed in the molar area, evaluated for 15 and 13 years, respectively. With the exception of the resections of the distal roots of mandibular molars, which had a $75 \%$ success rate, in the other roots it varied from 95 to $100 \%$. The implants had a success rate ranging from 97 to $98.6 \%$.

The aim of the study was to evaluate in each selected period (5, 8 and 10 years) the percentage of maintenance of molars that underwent root resection therapy with furcation lesions grade II and III or with root fractures, treated in a private clinic.

\section{MATERIAL AND METHOD}

The clinical assessments of patients were obtained from a private Periodontics clinic who underwent molar RR were evaluated. The study was registered at CEP - Unigranrio 04358712.2.0000.5283.
Surgical therapy in all cases was performed by a single operator. Patients received this therapy for general reasons: (1) Molars with moderate or advanced periodontitis, with furcation lesion grades II or III, (2) Molars with extensive fractures, caries or endodontic reason, in one of the roots. The supportive periodontal therapy was made for at least one annual session during the assessed time (5, 8 and 10 years). For the clinical therapy to be considered successful, the tooth is remaining in functional loading, should not have mobility above grade I, depth of the probing pocket $\geq 4$ $\mathrm{mm}$, absence of bleeding on probing or exudate, fractures and root caries (Fugazzoto).

Furthermore, relevant data pertaining to the rootresected tooth such as your location, specific resected root, reason for root extraction (periodontal, root fractures or endodontic, caries/restorative), history of endodontic treatment (before or after surgery) and type of final restoration (total crown, root-supported partial prosthesis, without crowns - composite or metal restorations MOD, MO or OD, and only root extracted exit restoration).

Statistical analysis: The Shapiro-Wilk test was used to determine if the values were parametric or not. The data collected were analyzed using the Kruskal Wallis test, for non-parametric data, and ANOVA. All differences were considered significant at $P<0.05$. Statistical analyses were performed using the BioEstat (2007).

\section{RESULTS}

Were evaluated the files of 37 patients, 15 males and 22 females, with a mean age of 51.4 (SD $= \pm$ 12.46), with a total of 44 teeth with RR, 27 upper molars and 17 lower molars.

The molars that underwent $R R$, the respective roots extracted, the reason for the extraction, and the type of prosthesis performed, total crown, total crown abutment of fixed partial denture, without crown (composite or metal restorations MOD, MO or OD, and only root extracted exit restoration) were described in Table I.

Out of 27 upper molars that underwent resection, MB root resections were performed in 06 cases, 05 teeth were rehabilitated with full crowns, DB root resections in 05 cases, 03 teeth rehabilitated with full 
Table I. Molars that underwent RR, the respective roots extracted, the reason for the extraction, and the type of prosthesis performed, total crown, total crown abutment of fixed partial denture, without crown (composite or metal restorations MOD, $\mathrm{MO}$ or OD, and only root extracted exit restoration).

\begin{tabular}{|c|c|c|c|c|}
\hline VARIABLE & & Total & Survival $10 \mathrm{y}$ & Failure 10y \\
\hline Ro ot resected $(n)$ & & 44 & $40(90,91 \%)$ & $4(9,09 \%)$ \\
\hline \multirow{4}{*}{ To oth type } & Maxfirst molar & $22(50 \%)$ & 20 & 2 \\
\hline & Max se cond molar & $5(11,36 \%)$ & 5 & \\
\hline & Mand first molar & $10(22,72 \%)$ & 8 & 2 \\
\hline & Mand second molar & $7(15,90 \%)$ & 7 & \\
\hline \multirow[t]{2}{*}{ Arch } & Maxilar & $27(61,36 \%)$ & 25 & 2 \\
\hline & Mandibular & $17(38,64 \%)$ & 15 & 2 \\
\hline \multirow[t]{7}{*}{ Resected root } & MB & $7(15,90 \%)$ & 7 & \\
\hline & DB & $4(9,09 \%)$ & 4 & \\
\hline & $\mathrm{P}$ & $15(34,09 \%)$ & 13 & 2 \\
\hline & Ro ot sepa ration & $1(2,27 \%)$ & 1 & \\
\hline & Me sial & $9(20,45 \%)$ & 9 & \\
\hline & Distal & $3(6,81 \%)$ & 2 & 1 \\
\hline & $\mathrm{HM}$ & $5(11.36 \%)$ & 4 & 1 \\
\hline \multirow[t]{3}{*}{ Reasons for root resection } & Furcation & $27(61,36 \%)$ & 26 & 1 \\
\hline & Endo - C/R & $12(27,27 \%)$ & 11 & 1 \\
\hline & Fracture & $8(18,18 \%)$ & 6 & 2 \\
\hline Types of restoration & MB & $2-3-2$ & & \\
\hline \multirow[t]{6}{*}{ TC - TCA - WC } & DB & $1-1-2$ & & \\
\hline & $P$ & $9-1-5$ & & $2-\mathrm{CT}$ \\
\hline & Ro ot separation & $1-0-0$ & & \\
\hline & $M$ & $1-8-0$ & & $1-\mathrm{TC}$ \\
\hline & $\mathrm{D}$ & $0-3-0$ & & \\
\hline & $\mathrm{HM}$ & $4-1-0$ & & $1-\mathrm{TC}$ \\
\hline
\end{tabular}

MB- mesio-buccal, DB- disto-buccal, P- palatal, HM - hemisection, TC - total crown, TCA - total crown abutment of fixed partial denture - FPD, WC - without crown

crowns and palatals root resections in 15 cases, 11 of which were rehabilitated with full crowns. In one of the teeth (case 17), a root separation was made between the vestibular roots and the palate and prosthetic tunneling, maintaining all the roots.

Of the total of 27 upper molars, 11 teeth were evaluated for 10 years, 8 teeth for 8 years and 8 teeth for 5 years. There were two losses, of two teeth with resection of the palatal root, one at 6 years old (case $15)$ due to fracture and another at 9 years old (case 10), due to the evolution of periodontal disease and increased mobility.

RR were performed on 17 lower molars, seven second molars and ten first molars, all rehabilitated with prosthesis. In 09 molars the mesial root was extracted and in 03 the distal root, and in all cases prosthetic crowns were made on the remaining root and splinted with an adjacent tooth. Hemisection was performed on 05 molars and in all cases the roots were splinted with prosthetic tunneling.
Of the total of 17 lower molars, 11 teeth were evaluated for 10 years, 3 teeth for 8 years and 3 teeth for 5 years. There were two losses, one tooth with resection of the mesial root due to fracture after 7 years (case 2) and another in which hemisection was made, due to caries in the furcation area (case 7 ), after 7 years of evaluation.

In the upper molars, the RR was indicated in 17 cases due to furcation lesion ( $62.9 \%), 4$ cases due to root fracture (14.8\%) and 6 due to restorative conditions $(22.2 \%)$. In the lower molars, the RR was done in 10 cases for furcation lesion (58.8\%), 4 for root fracture $(23.5 \%)$ and 3 for restorative or endodontic conditions $(17.6 \%)$. In all cases, endodontic treatment was performed prior to the surgical procedure.

The survival rates after the root resection was $97.73 \%$ for 05 years of evaluation (44 teeth), $95.35 \%$ for the 08 years of evaluation (43 teeth) and $97.57 \%$ for the 10 years of evaluation. evaluation (41 teeth). The survival rates after 10 -years was $90.91 \%$. 

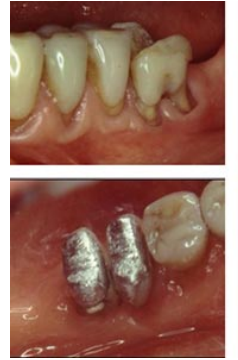

Fig. 1 up.
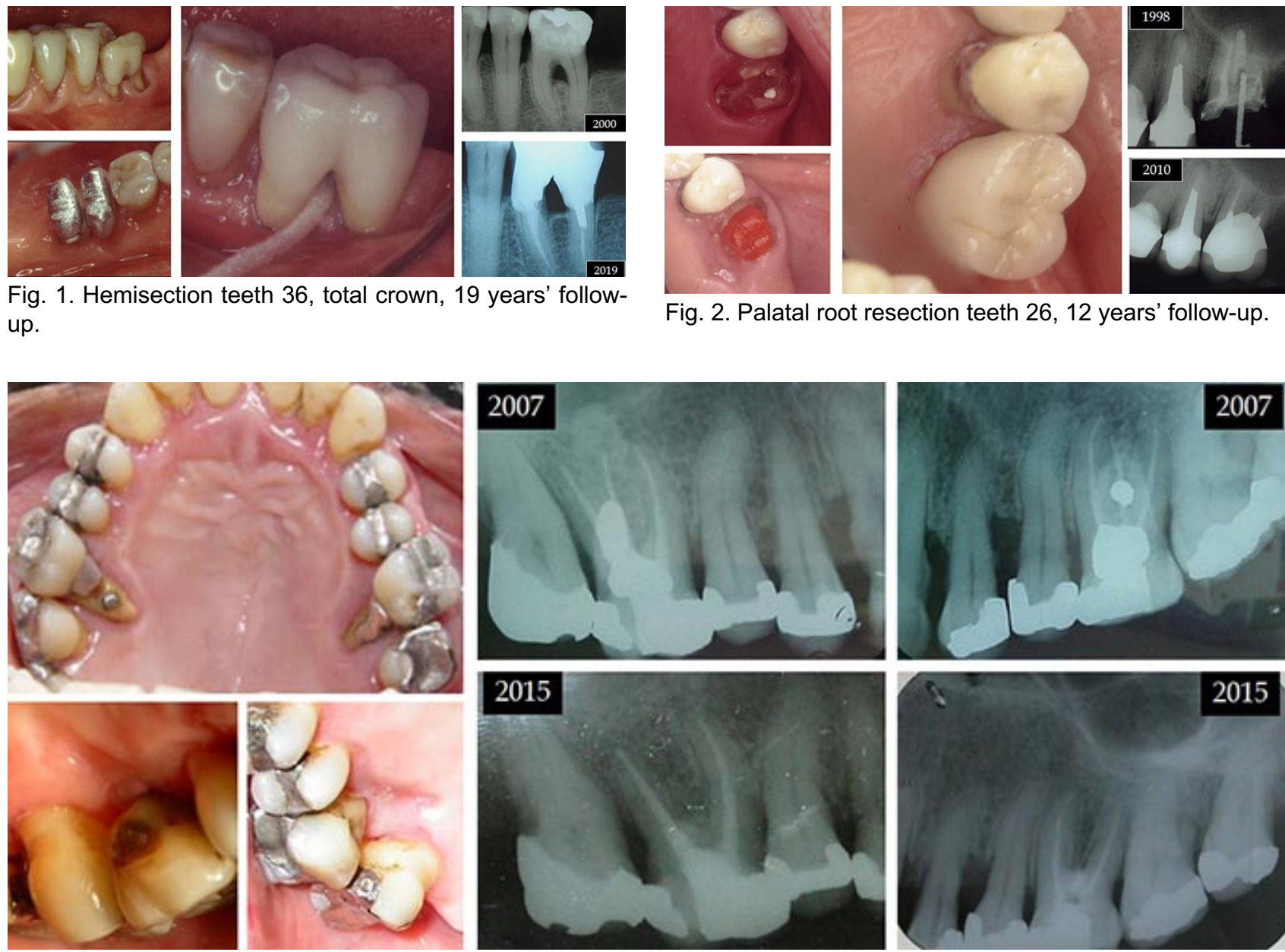

Fig. 2. Palatal root resection teeth 26,12 years' follow-up.

Fig. 3. Palatal root resection tooth 16 and 26,8 years' follow-up.
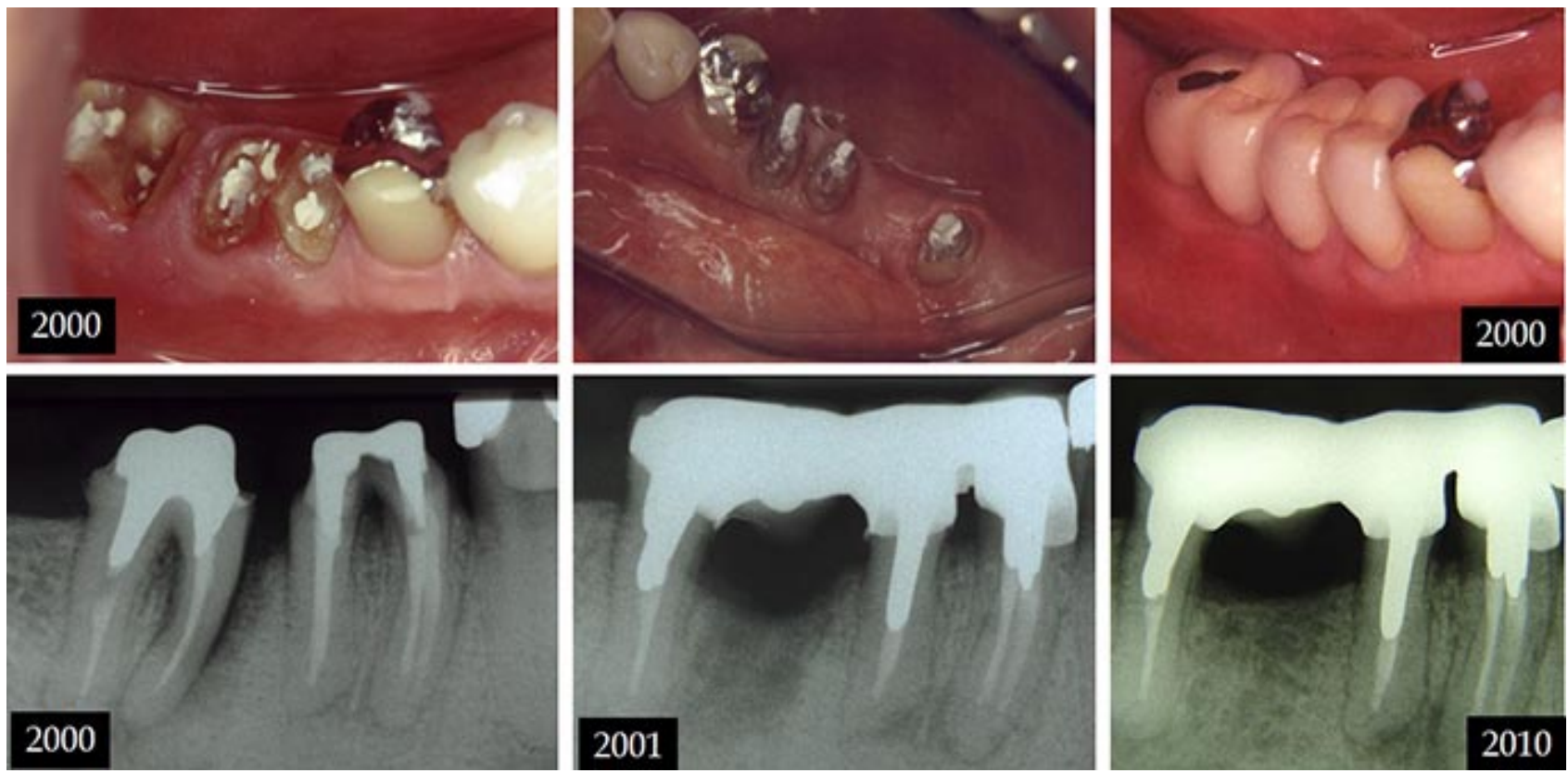

Fig. 4.Mesial root resection teeth 47, hemisection teeth 46, 10 years' follow-up. 

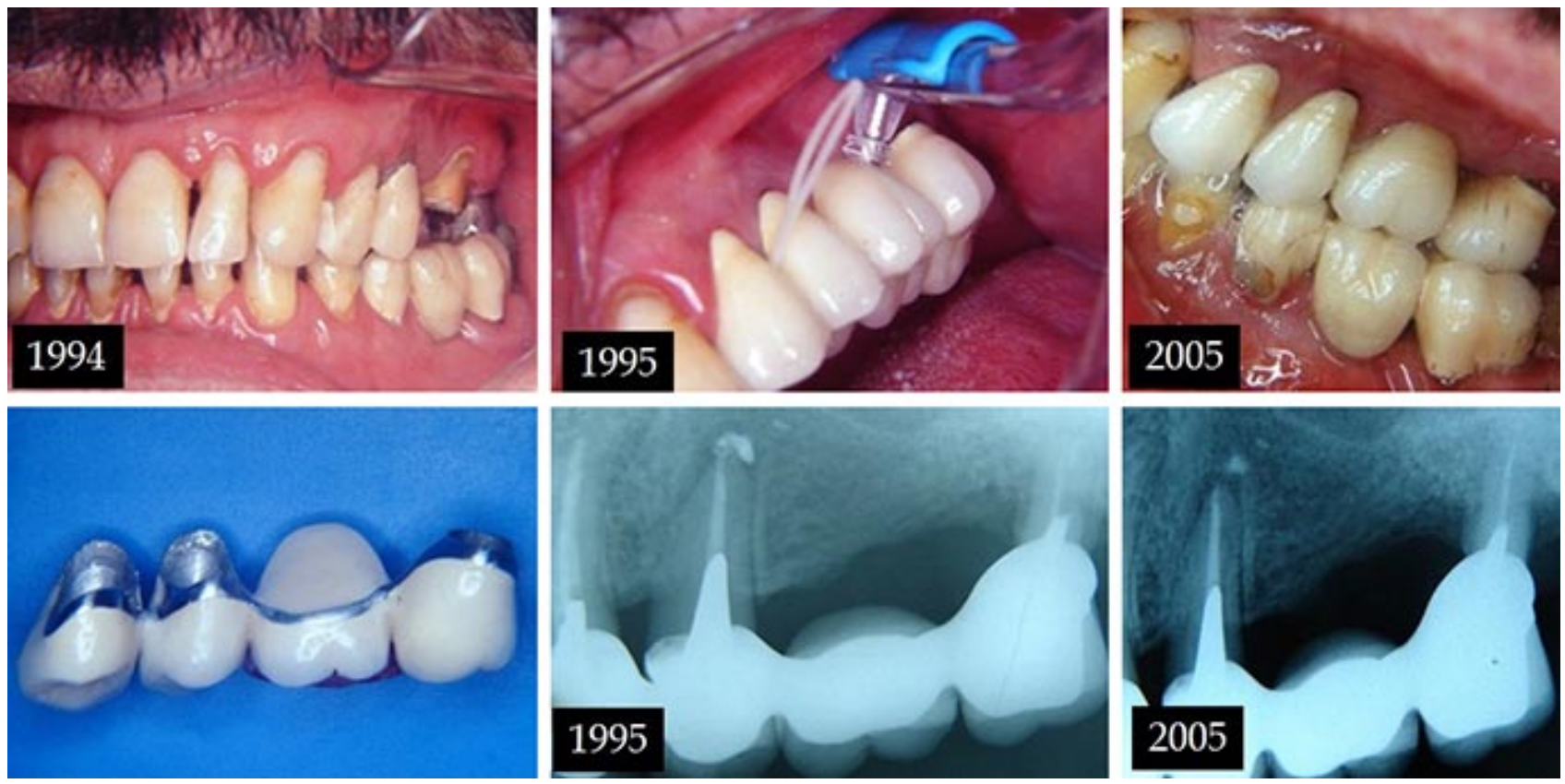

Fig. 5. Mesio buccal root resection teeth 26,10 years' follow-up

There was no statistical difference when comparing the types of restorations performed and the tooth survival rate $(p=0.61)$. In the upper molars, the palatal root is the most removed ( $p=0.00002)$ and in the lower molars the mesial root $(p=0.0006)$.

Figures 1 to 5 illustrate some cases of the study, some of which with results over 10 years.

\section{DISCUSSION}

Furcation lesions are the periodontal lesions with greater difficulty in treatment due to the anatomical conditions that hinder root instrumentation (Desanctis \& Murphy, 2000, Deliberador et al., 2009), even when surgical techniques are used for subgingival scalling (Nordland et al.).

Conservative therapies for the treatment of furcation lesions, have good results in maintaining teeth, mainly in association with periodontal support therapy, with success rates above $80 \%$ within up to 5 years (Svardstrom \& Wennstrom, 2000; Huynh- Ba et al.).

The $R R$ is a viable option for molar therapy with furcation lesions, before indicating extraction and replacement with implants or conventional prostheses (Alassadi et al., 2020). The results of this therapy are very varied, probably due to the case selection criteria, different surgical techniques and ways of restoring teeth (Almeida et al.). Carnevale et al., Fugazzotto and Derks et al. (2018) showed survival of teeth above $90 \%$ in evaluation for 10 years, which is similar to the results of this study that showed the maintenance of teeth in function of $90.91 \%$. Other studies show worse results with survival between 60 and $70 \%$, such as those of Park et al., Bühler et al. (1988) and Langer et al. (1981) with $70 \%, 68 \%$ and $62 \%$ respectively.

Tooth loss after RR occurs due to periodontal reasons, root fractures or caries / endodontic problems. In this study, only one loss was due to periodontal reasons ( $25 \%)$, according to the results of Alassadi et al. who showed $23 \%$ and Langer et al. $26.3 \%$ loss due to the evolution of periodontal disease. Probably periodic periodontal maintenance may have contributed to this fact. Losses due to endodontic reasons, fractures and caries were greater in the studies by Langer et al., Carnevale et al. and Fugazzotto. The occurrence of dental caries lesions in teeth with root resection is related to the quality of prosthetic preparations, especially in the manufacture of full crowns, especially in teeth with resection of the MB root. It is essential to reestablish periodontal tissue in order to create a morphology favorable to satisfactory plaque control (Carnevale et al.).

Fugazzoto reported root fractures in $17.3 \%$ of failures in root resections and Alassadi et al. $25.8 \%$. 
Root fractures occurred in two cases in this study, one of them in a mesial root resection of a first mandibular molar, where a unitary total crown without splint with the adjacent tooth was installed, a fundamental requirement for the success of lower molar resections (Rosenberg et al., 1992).

The indication of $R R$ in molars with a furcation lesion or impairment of one of the roots, is often faced with replacement by implants, and the cost-benefit of each procedure, such as duration of treatment, complexity and predictability of results, must be evaluated. Fugazzotto showed very similar effective results between root resections (over $95 \%$ ) and implants (over $97 \%$ ) in the molar area, after more than 10 years of evaluation. The use of implants to replace maxillary molars has more complicating factors, which should be evaluated, such as the position of the maxillary sinus floor, possible thin alveolar edges due to loss of periodontal attachment (Bühler et al., 1994), which may favor resection root. On the other hand, for RR, endodontic treatment is mandatory, and some prosthetic preparations may be difficult due to the final anatomy of the tooth. It should be noted that the indication for implants in individuals with a history of periodontitis should be well evaluated, as they may show a higher prevalence of perimplantitis than in patients without periodontal disease (Karoussis et al., 2003; Simonis et al., 2010).

In lower molars, the use of RR necessarily requires splinting of the remaining root with the adjacent tooth through a fixed prosthesis (Rosenberg et al.) to disperse occlusal forces and prevent root fractures (Sánchez-Pérez \& Moya-Villaescusa, 2009). In this study, 12 RRs were performed on lower molars with extraction of a root and in only one case was used a total crown isolated, resulting in fracture. This fact favors the use of implants that have a very good result in replacement of lower molars, in addition to preventing the prosthetic wear of adjacent teeth.

In this study, in a total of 44 teeth that were submitted to RR, 35 were rehabilitated with full crowns, splinted or not, according to the study by Hou et al. (1999) who indicated the restoration of teeth that passed through RR, with full crowns. In cases of hemisection in lower molars, in 4 cases the union of the two roots was made through a total crown with tunneling, which allows good hygiene and favors prosthetic stabilization due to the difficulty of making long nuclei in the mesial roots (Almeida et al.).
Park et al. reported that the upper molars with $R R$ of the DB and $P$ roots exhibited more failures, and in this study $15 \mathrm{RR}$ were performed on palatal roots with only two losses (13.3\%), according to Fugazzotto who showed no losses related to the removed root. The use of full crowns in these cases implies a reduction in the buccal-palatal extension of the prosthetic preparation, for the incidence of occlusal forces in the oral roots (Rosenberg et al.).

RR can be a treatment option for molars and show a favorable result in the functional survival of teeth. Well-planned cases with adequate indication, with correct endodontic, periodontal and restorative evaluation can be very long-lived, and RR should be considered before the indication of tooth extraction and use of implants.

\section{CONCLUSION}

- The survival rate of molars with RR was $90,91 \%$ in ten years of evaluation.

- The root resections were indicated in $61,3 \%$ of the cases due furcation lesions.

- The type of prosthesis had no influence on the survival rate of teeth with root resection.

FALABELLA, M. E. V.; DE SOUZA, R. J. S.; DORNELAS, A. H. C.; VIEIRA, A. D. D. \& SOARES, L. G. Resección de la raíz en molares: evaluación clínica durante 10 años. Int. J. Odontostomat., 15(2):492-498, 2021.

RESUMEN: La resección de la raíz (RR) es una opción terapéutica para lesiones de furca de grado II y III, fractura de una de las raíces y caries de la raíz. El objetivo del estudio fue evaluar en cada período seleccionado (5, 8 y 10 años) el porcentaje de mantenimiento de los molares que se sometieron a terapia RR con lesiones de furca de grado II y III o con fracturas de raíz. Los sujetos recibieron la terapia con RR en molares con periodontitis, con lesión de furca de grado II o III, y con fracturas, caries o razón endodóntica, en una de las raíces. La terapia periodontal de apoyo se realizó durante al menos una sesión anual durante el tiempo evaluado. Para que la terapia clínica se considere exitosa, el diente permanece en carga funcional, sin movilidad por encima del grado I, profundidad de bolsillo $\geq 4 \mathrm{~mm}$, ausencia de sangrado al sondaje o exudado, fracturas y caries de raíz. Se evaluaron los archivos de 37 pacientes, 15 hombres y 22 mujeres, con una edad média de $51,4(\mathrm{DE}= \pm$ $12,46)$, con un total de 44 dientes con RR, 27 molares superiores y 17 inferiores. Las tasas de supervivencia después del RR fueron del $97,73 \%$ durante 5 años de evaluación 
(44 dientes), 95,35 \% para los 8 años (43 dientes) y 97,57 $\%$ para los 10 años (41 dientes). Se restauraron 35 dientes con cuervos totales aislados los pilares de prótesis fija. Las tasas de supervivencia después de 10 años fueron del $90,91 \%$, y no hubo diferencia estadística entre los tipos de restauraciones realizadas y la tasa de supervivencia dental.

PALABRAS CLAVE: defectos de furca, enfermedades periodontales, prótesis dental.

\section{REFERENCES}

Alassadi, M.; Qazi, M.; Ravida, A.; Siqueira, R.; GaracicoaPazmiño, C. \& Wang H. L. Outcomes of root resection therapy up to 16.8 years: A retrospective study in an academic setting. J. Periodontol., 91(4):493-500, 2020.

Almeida, F. B. C.; Vieira, A. D. D. \& Falabella, M. E. V. Ressecção radicular na terapia das lesões de furca - revisão de literatura e relatos de casos clínicos. Braz. J. Periodontol., 22(4):6371, 2012.

Bühler, H. Evaluation of Root-Resected teeth. Results after 10 years. J. Periodontol., 59(12):805-10, 1988.

Bühler, H. Survival rates of hemisected teeth: An attempt to compare them with survival rates of alloplastic implants. Int. J. Periodont. Rest. Dent., 14(6):537-43, 1994.

Carnevale, G.; Pontoriero, G. \& Di Febo, G. Long-term effects of rootresective therapy in furcation-involved molars. A 10-year longitudinal study. J. Clin. Periodont., 25(3):209-14, 1998.

Cattabriga, M.; Pedrazzoli, V. \& Wilson Jr., T. G. The conservative approach in treatment of furcations lesions. Periodontol. 2000, 22(1):133-53, 2000.

Deliberador, T. M. Cirurgia periodontal ressectiva no tratamento dos defeitos de furca. Perspect. Oral. Sci., 1(1):49-54, 2009.

Derks, J.; Monje, A. \& Wang, H. L. Peri-implantitis. J. Clin. Periodontol., 45(Suppl. 22):246-66, 2018.

Desanctis, M. \& Murphy, K. G. The role of resective periodontal surgery in the treatment of furcation defects. Periodontol., 2000, 22(1):154-68, 2000.

Fugazzotto, P. A. A comparison of the success of root resected molars and molar position implants in furcation in a private practice: Results of up to 15 -plus years. J. Periodontol., 72(8):1113-23, 2001

Gusmão, E. S.; Picarte, A. L.; Bene Barbosa, M. C.; Rosing, C. K. \& Cimoes, R. Correlation between clinical and radiographic findings on the occurrence of furcation involvement in patients with periodontitis. Indian J. Dent. Res., 25(5):572-5, 2014.

Hou, G. L.; Tsai, C. C. \& Weisgold, A. S. Treatment of molar furcation involvement using root separation and a crown and sleeve-coping telescopic denture. A longitudinal study. J. Periodontol., 70(9):1098-109, 1999.

Huynh-Ba, G.; Kuonen, P.; Hofer, D.; Schimid, J.; Lang, N. P. \& Salvi, G. E. The effect of periodontal therapy on the survival rate and incidence of complications of multirooted teeth with furcation involvement after an observation period of at least 5 years: a systematic review. J. Clin. Periodontol., 36(2):16476, 2009.

Jenabian, N.; Haghanifar, S.; Maboudi, A. \& Bijani, A. Clinical and radiographic evaluation of bio-gen with biocolagen compared with bio-gen with connective tissue in the treatment of class II furcation defects: a randomized clinical trial. J. Appl. Oral. Sci., 21(5):422-9, 2013.
Karoussis, I. K.; Salvi, G. E.; Heitz-Mayfield, L. J.; Hämerlle, C. H. \& Lang, N. P. Long-term implant prognosis in patients with and without a history of chronic periodontitis: a 10- year prospective cohort study of the ITI Dental Implant System. Clin. Oral Implants Res., 14(3):329-39, 2003.

Kinsel, R. P.; Lamb, R. E. \& Ho, D. The treatment dilemma of the furcated molar: Root resection versus single-tooth implant restoration. A Literature Review. Int. J. Oral Maxillofac. Implants, 13(3):322-32, 1998.

Langer, B.; Stein, S. B. \& Wagenberg, B. An evaluation of root resections. A ten-year study. J. Periodontol., 52(12):719-22, 1981.

Nordland, P.; Garrett, S.; Kiger, R.; Vanooteghem, R.; Hutchens, L. H. \& Egelberg, J. The effect of plaque control and root debridement in molar teeth. J. Clin. Periodontol., 14 (4):2316, 1987.

Park, S. Y.; Shin, S. Y.; Yang, S. M. \& Kye, S. B. Factors influencing the outcome of root-resection therapy in molars: A 10-year retrospective study. J. Periodontol., 80(1):32-40, 2009.

Rosenberg M. M.; Kay, H. B.; Keough, G. E. \& Holt, R. L. Tratamento periodontal e protético para casos avançados. Rio de Janeiro, Quintessence Books, 1992.

Sánchez-Pérez, A. \& Moya-Villaescusa, M. J. Periodontal disease affecting tooth furcations. A review of the treatments available. Med. Oral Patol. Oral Cir. Bucal, 14(10):554-7, 2009.

Simonis, P.; Dufour, T. \& Tenembaum, H. Long-term implant survival and success: a 10-16-year follow up of submerged dental implants. Clin. Oral Implants Res., 21(7):772-7, 2010.

Svärdström, G. \& Wennström, J. L. Periodontal treatment decisions for molars: An analysis of influencing factors and long-term outcome. J. Periodontol., 71(4):579-85, 2000.

Walter, C.; Weiger, R. \& Zitzmann, N. U. Periodontal surgery in furcation-involved maxillary molars revisited - an introduction of guidelines for comprehensive treatment. Clin. Oral. Investig., 15(1):9-20, 2011.

Wang, H. L.; Burgett, F. G.; Shyr, Y. \& Ramfjord, S. The influence of molar furcation involvement and mobility on future clinical periodontal attachment loss. J. Periodontol., 65(1):25-9, 1994.

Corresponding author:

Márcio Eduardo Vieira Falabella

Periodontics, Associate Professor

Dental Clinical Department

School of Dentistry

Federal University of Juiz de Fora

Minas Gerais

BRAZIL

E-mail: mevfalabella@hotmail.com 